DOI: https://doi.org/10.34069/AI/2021.44.08.19

How to Cite:

Izotova, N., Polishchuk, M., \& Taranik-Tkachuk, K. (2021). Discourse analysis and digital technologies: (TikTok, hashtags, Instagram, YouTube): universal and specific aspects in international practice. Amazonia Investiga, 10(44), 198-206. https://doi.org/10.34069/AI/2021.44.08.19

\title{
Discourse analysis and digital technologies: (TikTok, hashtags, Instagram, YouTube): universal and specific aspects in international practice
}

\section{Дискурс і цифрові технології (TikTok, hashtags, Instagram, YouTube): універсальні і специфічні аспекти в міжнародній практиці}

Received: August 7, 2021

Accepted: September 25, 2021

\begin{abstract}
Nowadays, digital communication helps people to establish contact quickly and conveniently, to convey their message, ideas, the vision of the world to a wide audience. In this regard, new challenges have emerged for discourse analysis in the field of research on the features of digital communication, digital communication practices, the impact of electronic communication technologies on the formation and conduct of discourse, application, and influence of extralinguistic factors on speech. The article analyzes the problems and features of discourse using digital technologies, current trends, and new data in the field of social networks, hashtag activism, problems of involvement, activity, motivation of participants in online communication, formation of their online identity. The authors used systemfunctional, hermeneutic methods, linguistic analysis, methods of analysis, and synthesis in the framework of discourse theory. The study found and confirmed that the features of digital communication practices and the formation of discourse on the Internet are the widespread use of social networks, hashtags, social integration activities such as challenges, the use of special vocabulary specific to Internet communication,
\end{abstract}

\begin{abstract}
Анотація
Цифрова комунікація в наш час допомагає людям налагодити контакт швидко та зручно, донести своє повідомлення, ідеї, бачення світу до широкої авдиторії. У зв'язку з цим, для дискурс-аналізу постали нові виклики в царині досліджень особливостей цифрової комунікації, цифрових комунікативних практик, впливу технологій електронної комунікації на формування та ведення дискурсу, застосування та впливу екстралінгвістичних факторів на мовлення. У статті аналізуються проблеми та особливості дискурсу із застосуванням цифрових технологій, актуальні течії та нові дані в галузі соцмереж, хештег-активізму, проблем залучення, активності, мотивації учасників онлайн комунікації, формування їх онлайн ідентичності. Автори використали системнофункціональний, герменевтичний методи, лінгвістичний аналіз, прийоми аналізу та синтезу в рамках теорії дискурсу. У результаті дослідження встановлено та підтверджено, що особливостями цифрових комунікативних практик та формування дискурсу в мережі Інтернет є розповсюджене використання соцмереж, хештегів, проведення таких заходів соціальної
\end{abstract}

\footnotetext{
${ }^{76}$ Doctor of Philology, Associate Professor, Professor of the Department of English Philology, Translation and Philosophy of Language named after Professor Morokhovsky, Kyiv National Linguistic University, Kyiv, Ukraine.

77 Teacher of the Department of Foreign Languages No. 1, National University "Odesa Law Academy", Odesa, Ukraine.

${ }^{78}$ Candidate of Pedagogical Sciences, Associate Professor, Department of Ukrainian Philology and Slavic Studies, Kyiv National Linguistic University, Kyiv.
} 


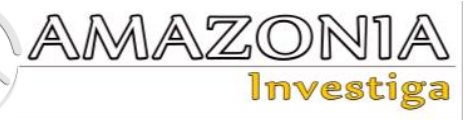

the ability to express themselves and form their own online user identity. Extralinguistic factors of discourse formation in digital communicative practices are major from the point of view of discourse analysis.

Keywords: discourse, digital technologies, digital communication, digital communication practices, discourse analysis.

\section{Introduction}

Information technology is changing the world. Today, this thesis does not look like an exaggeration but reflects the objective processes taking place in the world.

Modern technologies affect various spheres of life: from television to education, from rocketry to linguistics. Of course, linguistics changes more slowly than the media market, but these changes are fundamental. The invention of the Internet and the proliferation of online media and social networks have led to a real communication revolution, the same as that once caused by the advent of the printing press. Not only have the methods of communication changed, but also the structure, stylistics, and content of the relevant texts.

Instant messaging systems, simulation 3D games, "Internet of Things", "smart technologies", "mobile reporting" techniques, and other attributes of modern social reality, undoubtedly simplify our lives, making them more comfortable and more interactive (that is social), but at the same time are still "closed" for study. What is new in communication when people use Viber? What determines our interpretation of the content posted on the Web largely - the content itself or the comments to it? What does a person do socially significant when he likes a post on a social network? Do computer games form knowledge systems comparable to those formed by books or everyday speech communication? What does the hashtag have to do with the content of the message or with the conditional classification of reality? Does watching videos on YouTube affect the picture of the world of Web users? These questions remain unanswered largely because we do not yet know how to answer them.

The study aimed to analyze the features of the formation of discourse using digital

інтеграції як челенджі, використання особливої лексики, характерної саме для інтернет-комунікації, можливість самовираження та формування власної онлайн ідентичності користувачів. Важливими 3 точки зору дискурс-аналізу $\epsilon$ екстралінгвістичні фактори формування дискурсу в цифрових комунікативних практиках.

Ключові слова: дискурс, цифрові технології, цифрова комунікація, цифрові комунікативні практики, дискурс-аналіз.

communication technologies, respectively, to pay attention to such phenomena as digital communication practices, and other relevant phenomena in the environment of digital communication.

\section{Theoretical Framework or Literature Review}

Discourse analysis and digital technologies are topical areas of research. The very concept of discourse has also been given enough attention to form a theoretical, conceptual basis of discourse analysis in which the study took place. For example, in the works of Fairclough (1995, 2013), van Dijk (1995, 2008, 2009), we can find the necessary theoretical framework for critical discourse analysis, research, discourse theory, the relationship of concepts of power and communication, the role of media in the formation of power discourse, pragmatics of discourse analysis, etc. Earlier, Foucault (2005, 2013), in his research, substantiated the relevance of discourse theory, introducing his ideas about the features and limits of its study (Hook, 2007). Papacharissi (2002, 2013) and Marwick (2013) study the analysis of the formation of online identity and the issues of representation in the media. Jones, Chik, and Hafner (2015) and Kozhemyakin (2016) specifically address discourse analysis and digital technologies.

\section{Methodology}

We used the system-functional method to characterize how discourse manifests itself in digital communication using digital technologies. Hence, we have shown that online communication is a systemic phenomenon, and has its characteristics in different conditions. For example, this can be expressed in online activism (use of tags with social, political context, the call to action), involvement in social activity in the 
form of challenges in the social network, building a strategy of communication with subscribers, and the formation of online identity following the real priorities of social interaction and goals of online communication. Thus, it was demonstrated what features of the online communication system perform the corresponding functions in digital communication practices. We also analyze the relationship in the communication system between the addressee, the addressee, the context in which their communication is immersed, the means and methods they use for their communication, the extralinguistic factors of discourse formation, and its functions in online communication.

The authors applied the hermeneutic method to demonstrate the impact of changes in modern communication on the perception of theoretical concepts of communication as such. For example, it explains what changes in digital communication practices mean for the ontological status of communication, as well as how culture changes under the influence of digital technologies; explains the content and functions of current online communication and the values that are inherent in it.

Linguistic analysis was conducted to show the features of communication in their word-forming expression in the context of online discourse. To do this, we confirm what words are specific to website platforms, their meaning, functions, and origins, the difference between the lexicon in various social networks and its role in communication and the formation of online user identity, the development of their communication strategy.

\section{Results and Discussion}

\section{Discourse analysis and digital communications. Approaches to the problem}

Traditional approaches and methods, addressed to the analysis of mainly oral and written verbal texts, are less and less satisfying our needs in the study of polycode, multimodal, and multimedia digital phenomena. Classical theoretical models of communication (from Harold Lasswell to Umberto Eco) are less and less able to explain the nature of communication between people on social networks. The tools of critical analysis of ideology and power are insensitive to the new forms of "soft power" and ideological control that are used in the digital communicative space. All this makes the problem of describing the latest communication revolution in the full sense a methodological problem.

Information technology has an impact on a person, his/her thinking, and language. And if the change of communication under the influence of technology causes certain changes in the mental activity of people and forms a new style of this thinking, that change in the nature and content of thinking has a significant effect on language, which is organically connected with thinking, is a means of communication, a material shell of thinking. Therefore, working with a computer, interacting with it changes the character interpersonal communication of people themselves, defines completely new features of this communication.

Is it possible to consider the discourse in this way during the transition period, when there are changes in the communication of ordinary citizens? From the point of view of Michel Foucault, it is unlikely, because to examine discourse, the researcher should distance himself from it historically or spatially, thus going beyond discourse, explaining it, creating his metadiscourse with which to analyze the one beyond which he went. (Foucault, 2005, 2013; Hook, 2007).

With the development of the methodological basis of discourse analysis came the opportunity to interpret it from within, during the process of change. At the same time, there is a need for constant testing of new tools for suitability for the analysis of current phenomena, which, moreover, are constantly changing under the influence of scientific and technological development and the emergence of new trends in communication.

To adequately perceive changes in modern communication, it is possible to analyze them in the framework of discourse theory. It is necessary to perceive the discourse not as a set of texts, statements on a given topic but as a social practice (Kozhemyakin, 2016). The above means that it takes into account not so much the context of dispositions or knowledge but the context of communicative acts carried out by appropriate means, such as printed text, messages, posts, to fulfill their role in the social group (Jones, Chik, $\&$ Hafner, 2015). Thus, communicative practices (with the use of digital technologies) become the object of discourse analysis and acquire discursive properties.

In this sense, from the point of view of structuralism, attention should be paid to the 


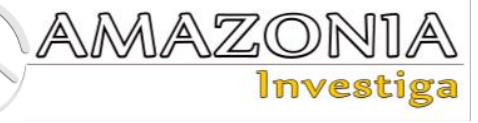

means, tools, or products of communication. However, in the aspect of discourse analysis, we should be interested in the process of producing the meaning of digital communication, which is expressed in the text or other forms of information transmission. Thus, such discourse practice is part of the sociocultural practice. The process of creating and consuming text is also a discourse practice. In turn, the communicative event is part of the social and cultural processes that come together in sociocultural practice (Fairclough, 1995).

\section{Is online communication analogous to face-to- face communication?}

The use of digital technologies becomes essential in the life of society when they are used to perform acts of communication between people (communicative acts). For example, when a child reads a story from a tablet, calls each other on Facetime, participates in an online conference these are communicative acts that have an expression in the real, analog world however can be carried out using digital technology. Their content does not change, but the format of their implementation affects perception.

From the point of view of theory, there is a question of the relationship between the virtual and the digital, in particular, concerning the ontological status of communication that takes place with the help of digital technologies. For example, Kozhemyakin (2016) points out that criticism is aimed at the fact that online communication is not an analogue of communication in life, can not be put on a par with it, therefore, to conduct discourse analysis using its tools is inappropriate. In this case, the status of online communication does not correspond to the communication that we used to perceive as the exchange of information between two full-fledged subjects. Rather, it is a balance with a digital "avatar". However, not everyone shares this view. For example, Jones, Chik, \& Hafner (2015) point out that online communication is no less real than ordinary faceto-face communication, given the reality of social goals set by communicators in the process of communicating online and their compliance identities to these goals. In other words, when communication is honest, transparent, open, clear, unambiguous, and its subjects do not pretend to be who they are not, there should be no significant difference, whether it is in real life or online. So, from this point of view, the tools of discourse analysis, a critical look at what social roles are assigned to the addressee and the addressee, what is the context of their communication, what linguistic techniques they use, what they mean - all this becomes applicable to communication on the Internet, which is done through digital technology. For example, the socalled chat rooms (websites for chatting with other people in a chat format, where messages appear from top to bottom - new under the previous) do not virtualize sexual intercourse, they are not cybersex platforms (King, 2015). At the same time, they promote the social integration of communication participants through their communication on sexual topics, which is analogous to flirtation and courtship, only in digital form. Thus, the line between online and offline discourse is shaky, it is easily blurred when the features of digital communication (Internet slang, linguistic features of language or writing on the Internet, game jargon, etc.) sound in everyday life.

\section{Online identity and representation as part of discourse formation}

Online identity formation and representation in social media is the focus of theoretical research in the field of social communications (Subrahmanyam \& Šmahel, 2011; Marwick, 2013). Identity can mean how we think about ourselves (subjectivity), how different aspects of identity are portrayed in culture and the media (representation), or how we present ourselves to others (representation, or self-presentation) (Marwick, 2013). This can mean our personal or social identity as a member of the group (ibid). Marwick (ibid) points out that the main subject of research in this aspect is the representation (Wynn \& Katz, 1997; Papacharissi, 2002, 2010; Baym, 2010). When creating a social network profile, starting your blog, or microblogging, one of the first tasks is to fill in information about yourself or the person / organization / institution you represent. In this sense, the discourse that people choose to provide to the public as information about themselves, for example, in such social media as Facebook and Twitter, is interesting for discourse analysis. In addition, the identity is constructed based on interaction with other users: likes, reposts, comments, etc. These are integral parts of online identity formation. The main idea is that, in contrast to face-to-face contact, the observer of someone else's identity on the Internet can open more information for analysis, plus it will be in constant open access. For example, these can be photos with friends, marks (geolocation) of places where a person has visited, likes under posts on a specific topic, the content of posts and comments under them, etc. In this aspect, the main thing to emphasize is that the analysis of discourse opens not only the 
sphere of speech, directly engraved in the text message but a whole array of personal data that can be used by him to form his identity online (representation). Accordingly, a person can consciously form his discourse, choosing the means of self-presentation as an extralinguistic factor in the formation of discourse, plus to form communication with others, having data about his audience, thus trying to establish effective and influential communication with others, using linguistic techniques to form communication or specific topics, which, in turn, complements the identity of the speaker and contributes to the goals of his representation on social media. Even e-mail addresses and nicknames can be part of the discourse, as the person thus complements his or her identity with individual details.

\section{Social networks. Why do people sit in them, and why discourse analysis?}

A feature of the social network TikTok was the use of veiled vocabulary, euphemisms, the use of figurative words to circumvent the rules of this network, which does not allow public access to hashtags that have a clear sexual meaning (Anderson, 2020). (You may not: intimidate or harass another, or promote sexually explicit material, violence, or discrimination based on race, sex, religion, nationality, disability, sexual orientation, or age (Section 5 of TikTok's Terms of Service as of February (2021).) To do this, users use various characters to encrypt a hashtag or word that is prohibited by community rules (content is constantly checked, moderated, and deleted if necessary). Similar rules apply to the social network Instagram. Emoji can also be used to hide a specific word. A feature of the discourse on Instagram can be considered, what is called the content plan and strategy of communication with the audience (Shafigullina \& Palyakin, 2016). In this way, users try to attract as many subscribers as possible, expand their influence to the largest possible audience, plus, if possible, commercialize their authority by turning the distribution of their content into financial assets (Ahmadinejad \& Najafi Asli, 2017). For example, legal entities whose purpose is to make a profit, for obvious reasons, form their communication with customers accordingly. In this, they are also helped by the formation of an appropriate image, which serves as a link to their reputation and representation - positioning themselves in the digital environment and the market. The situation with individuals is similar, as it involves tools for successful communication, expanding the audience, forming an attractive image, etc. We can say that the struggle is for a modern digital currency - for influence on the Internet and for the attention of users. This shows the direction of the discourse in social networks.

\section{How exactly does this work? Influencing factors and motivation}

The peculiarities of the formation of discourse on such platforms as Instagram and TikTok are the holding of challenges and flash mobs - types of a social activity integrated into the digital space, which under a specific slogan unites people to perform certain actions specifically for such actions. For example, \#tenyearchallenge was popular on social media in January 2019, reaching 2.5 million mentions in one month (Mathew, 2021). In addition to ordinary people, celebrities took part in it, showing how they have changed in ten years. Prior to that, in August 2014, \#icebucketchallenge helped attract a large number of people and public patrons such as Bill Gates to participate in a campaign to attract attention and donate to the research and treatment of amyotrophic lateral sclerosis (ALS) (Koohy \& Koohy, 2014; Pressgrove, McKeever, \& Jang, 2018). (Amyotrophic lateral sclerosis (ALS) is an idiopathic, fatal neurodegenerative disease of the human motor system (Kiernan et al., 2011).) As a result, five years later, the ALS Association reported a $187 \%$ increase in disease research spending (Frederick, 2019). It should be supplemented that the reasons for the virality (growing popularity) of a challenge are the desire of participants to be part of social interaction (participants in a communicative act, to be part of society, to socialize), receiving a positive emotional response, psychostimulative effect of social communication (excitement, fun), that the participants in the challenge are involved in an important event, and from the outside, there are many like-minded people, the same people as them (Mathew, 2021). Such challenges affect our group instinct, the desire to be seen and heard, to be part of a group, to be "our own". Thus, challenges in social networks promote the social integration of a large number of people, are part of social activity, and can be aimed at achieving specific goals, such as addressing the public eye on social issues or attracting donations to charity. TikTok users, who surpassed Facebook in the number of downloads in 2020 (BBC News, 2021) and YouTube in the US on the Android platform by the number of hours of viewing (Porter, 2021), are most often the preservation of interesting content (archiving), the need for selfexpression, social interaction, and the desire to escape from reality (escapism) (Omar \& Dequan, 2020). From this point of view, a mobile application is only a means of expressing 


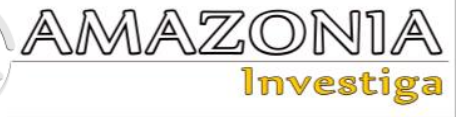

yourself and your emotions, ideas, achieving goals and objectives. Accordingly, it depends on the formation of their discourse and building communication with other people. We can say that people go to social networks for the same purpose for which they enter into communicative interaction offline, just with the help of digital means to make it easier, more convenient, and faster, plus there is an opportunity to reach a large number of recipients.

The motivation for attracting users to YouTube video hosting, which is currently the main competitor to TikTok (Porter, 2021), is the entertaining, relaxing effect of video content (Khan, 2017). The number of likes or dislikes will depend on this. Video commentary correlated with the desire to express one's position, while video commentary and video distribution played an informative role. Over time, more experienced YouTube users become more demanding of the videos they like, and male users are more likely to put dislikes than women.

\section{Use of hashtags. Hashtag activism - the power struggle?}

The use of hashtags to convey information in a concise, concentrated form is a common practice of communication in the field of digital technologies, the Internet, in particular, social networks. Tags such as \#MeToo, \#TimesUp, \#BlackLivesMatter have become part of the feminist movement and the fight against discrimination against social groups based on skin color, race, ethnicity, etc. (Jackson, Bailey, $\&$ Welles, 2020) These civic activism campaigns on and off the social network got their names from these hashtags. The above tags are most common in the United States, but social groups in other countries seek to achieve the same spread of information campaigns (for example, \#JeNeSuisPasCharlie in France as a reaction to the attack on the satirical magazine Charlie Hebdo), so the use of hashtags to spread a clear message is optimal Internet communication strategy in all countries.

Hashtag activism occurs when many posts appear on a social network, combined in one expression or phrase, in the form of a hashtag that contains a social, political claim or criticism (Yang, 2016). Since the main thing is the rapid and comprehensive dissemination of propaganda information to protect other social groups, groups of individuals or individuals, the nature of such a phenomenon as hashtag activism is common to all countries, the only difference is access to communication technologies, their prevalence, hence the scale and consequences of information campaigns. To gain momentum, it is not enough for the hashtag to be accurate, clear, concise, and clearly convey information about the social demand or dissatisfaction and demands of the activist movement. First of all, this social request must exist objectively, plus, there must be an appropriate number of caring people who will decide not only to read the post under the hashtag but also to disseminate information. This ability is generated by the context, cultural background, and understanding of symbols, semantics of information (Campbell, 2005), which is formed in the appropriate reaction of the recipient. This can serve as a "green light" for the perception of political / social message, and interfere with its perception because in the mind of the recipient there are opposite social attitudes, values, and norms of behavior that can put him in opposition to the movement of civic activism, or lack of certain ideas and attitudes will lead to indifference in his perception. Therefore, the recipient of the discourse responds not so much to the message itself, the hashtag, but to the social conditions in which his worldview was formed. From this point of view, the narratives used by hashtag activism are not independent of culture and context (van Dijk, 2009). They, like discourse, are speech, text immersed in context. A fundamentally important question is how and why hashtag activism is accompanied by acts of civil disobedience. Do the personal factors, biology, and psychology of the people involved play a role in this? Are there social factors that affect the level of struggle of social groups, discrimination against each other? For example, Bonilla \& Rosa (2015) point out that the appeal to activism on social networks is influenced by the distorted representation in the media of persons involved in acts of public disobedience. They are supported by other researchers, who point out that the use of hashtags in the activist movement for minority rights, against racial, sexual, and other forms of discrimination, is not accidental (Berridge \& Portwood-Stacer, 2015; Clark, 2016; Yang, 2016). Thus, they address the nature and origin of hashtag activism in favor of objectively existing social factors of discontent and anti-discrimination, without which the dissemination of campaign materials against them is unlikely, as they are doomed to drown in information noise without the necessary support. The ability to present information in such a way as to form a special story in the mind of the reader, which should evoke an emotional response, is regarded as successful storytelling. It plays a role in whether the dissemination of the information campaign will play out and whether 
its citizens will support it. Thus, communication between the addressee and the recipients is formed utilizing digital communication, which is very similar in content to a communicative act aimed at extending power and authority to voters by persuading them through linguistic techniques, rhetoric that affects their emotional state and values. In this sense, the discourse analysis of hashtag activism suggests that this phenomenon is related to the notion of power, authority, and political struggle (van Dijk, 2008).

\section{Digital communication practices. Their significance and role for discourse analysis}

Jones, Chik, \& Hafner (2015) suggest naming human processes / activities on the Internet or using electronic means of communication, digital communication practices. In more detail, they characterize this as the use of digital technology to achieve socially primary goals, the actualization of social identities, and the reproduction of social relations. Semiotic and discourse meanings play a fundamental role in defining digital communication practices in contrast to the technological or softwarehardware content of the term (Kozhemyakin, 2016). The authors of the proposed term especially emphasize the practical aspect, essential for the researcher who conducts discourse analysis based on digital communicative practices. Accordingly, the challenge is to discover how to do this (Jones, Chik, \& Hafner, 2015). To do this, they turn to the definition of conditions, means, effects of meaning-making, in particular, in the computermediated and digital environment (Kozhemyakin, 2016). Discourse in this sense refers to how semiotic systems affect the construction and management of social reality (Jones, Chik, \& Hafner, 2015). The way to study discourse here is a critical analysis of texts and contexts, the interaction of concepts of power and ideology (Fairclough, 2013).

Thus, discourse analysis applies to the study of the transition from one sign system to another and the application of contexts in new conditions ("contextual reframing") (Kozhemyakin, 2016). The so-called "knowledge construction", when hashtag activity forms a new phenomenon in social communication, can also be studied through discourse analysis. Additionally, intertextual and interdiscursive connections can be explored in terms of discourse analysis to study the social background behind the formation of digital communication. From a practical point of view, the use of the results of discourse analysis of digital communication should promote the development of critical thinking, such as children and adolescents, finding the meaning of power discourse, the formation of critical media literacy (Jones, Chik, \& Hafner, 2015). This is important for forming an appropriate culture of critical thinking and contributing to the goals of sustainable development and the development of a democratic formation oriented towards democratic values (van Dijk, 1995). Such a model potentially changes the role of studying the linguistic methods of discourse, which can be studied in the education system, causing new perspectives in this direction (Kozhemyakin, 2016). According to Jones, Chik, \& Hafner (2015), discourse analysis helps to clarify the mechanisms of semiotic construction of identities and social division of the world by participants in educational communication in the digital age. At the same time, they note that the tools of discourse analysis are largely inferior to the pace of development of digital communication technologies, so the adaptation of the theoretical basis may not keep up with innovation and take some time to adapt their optics to new changes.

\section{Conclusions}

The digital world is evolving rapidly. To ensure adequate consideration of linguistic techniques, the meanings of speech used in the network, discourse analysis tools can be used. With their help, it is possible to establish that digital platforms, website platforms are only the territory of expression of ideas, emotions, tasks, and goals that are inherent in people and live communication. From this point of view, the hardware and technical content of discourse on the Internet is not so much interested in discourse analysis as to how it affects the construction of social reality, i.e., the extralinguistic aspect of discourse formation in digital communication. Features of the discourse of digital communications are communication in social networks, the use of hashtag activism, the formation of online identity (representation) using discourse tools, factors influencing activity (involvement) in social networks (communication motivation), social integration (activity) through challenges, etc. Thus, digital communication is a promising and multifaceted area for further research, which, in our opinion, should focus on the latest trends in online communication and analysis of certain features of discourse on the Internet, the relationship of digital communication discourse, digital communication practices, and concepts of power, 


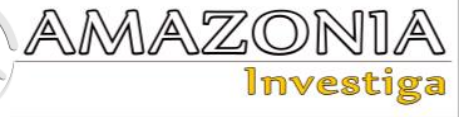

dominance, social justice, anti-discrimination, and inequality.

\section{Bibliographic references}

Ahmadinejad, B., \& Najafi Asli, H. (2017). E-business through Social Media: a Quantitative Survey (Case Study: Instagram). International Journal of Management, Accounting and Economics, 4(1), 80-99. Recovered from https://www.researchgate.net/publication/32 0614914_E-

business_through_Social_Media_A_Quantit ative_Survey_Case_Study_Instagram

Anderson, K.E. (2020). Getting acquainted with social networks and apps: it is time to talk about TikTok. Library Hi Tech News, 4(37), 7-12. Recovered from https://doi.org/10.1108/LHTN-01-20200001

Baym, N.K. (2010). Personal Connections in the Digital Age. Malden, MA: Polity

BBC News. (August 10, 2021). TikTok named as the most downloaded app of 2020. Recovered from https://www.bbc.com/news/business58155103

Berridge, S., \& Portwood-Stacer, L. (2015). Introduction: Feminism, hashtags and violence against women and girls. Feminist Media Studies, 15(2), 341-341. doi:10.1080/14680777.2015.1008743

Bonilla, Y., \& Rosa, J. (2015). \#Ferguson: Digital protest, hashtag ethnography, and the racial politics of social media in the United States. American Ethnologist, 42(1), 4-17. doi:10.1111/amet.12112

Campbell, K.K. (2005). Agency: Promiscuous and protean. Communication and Critical/Cultural Studies, 2(1), 1-19. doi:10.1080/1479142042000332134

Clark, R. (2016). Hope in a hashtag: The discursive activism of \#WhyIStayed. Feminist Media Studies. doi:10.1080/14680777.2016.1138235

Fairclough, N. (1995). Media discourse. London: E. Arnold

Fairclough, N. (2013). Critical discourse analysis: The critical study of language. London: Routledge.

Foucault, M. (2005). The Order of Things. London: Routledge.

Foucault, M. (2013). Archaeology of Knowledge. London: Routledge.

Frederick, B. (June 4, 2019). Ice Bucket Challenge dramatically accelerated the fight against ALS. Recovered from https://www.als.org/stories-news/ice-bucket- challenge-dramatically-accelerated-fight-

against-als

Hook, D. (2007). Discourse, knowledge, materiality, history: Foucault and discourse analysis. In Foucault, psychology and the analytics of power (pp. 100-137). Palgrave Macmillan. Recovered from https://link.springer.com/chapter/10.1057/97 80230592322_4

Jackson, S.J., Bailey, M., \& Welles, B.F. (2020). HashtagActivism: Networks of race and gender justice. MIT Press. Recovered from https://direct.mit.edu/books/book/4597/Hash tagActivismNetworks-of-Race-and-GenderJustice

Jones, R.H., Chik, A., \& Hafner, C.A. (2015). Discourse and digital practices: Doing discourse analysis in the digital age. London: Routledge. ISBN 9781138022331 Recovered from https://www.routledge.com/Discourseand-Digital-Practices-Doing-discourseanalysis-in-the-digital/Jones-ChikHafner/p/book/9781138022331

Khan, M.L. (2017). Social media engagement: What motivates user participation and consumption on YouTube? Computers in human behavior, 66, 236-247. Recovered from https://doi.org/10.1016/j.chb.2016.09.024

Kiernan, M.C., Vucic, S., Cheah, B.C.,(2011). Amyotrophic lateral sclerosis. The Lancet, 377(9769), 942-955. doi:10.1016/S0140-6736(10)61156-7.

King, B.W. (2015). Investigating digital sex talk practices: A reflection on corpus-assisted discourse analysis. In Discourse and Digital Practices (pp. 142-155). Routledge.

Koohy, H., \& Koohy, B. (2014). A Lesson from the Ice Bucket Challenge: Using Social Networks to Publicize Science. Frontiers in Genetics, 5, 430. Recovered from https://doi.org/10.3389/fgene.2014.00430

Kozhemyakin, E. (2016). Discourse Analysis in the Digital Age: Empowering. New Literary Review, 2 (138), 330-337. Recovered from http://www.intelros.ru/readroom/nlo/1382016/30038-diskurs-analiz-v-cifrovuyuepohu-rasshirenie-vozmozhnostey-rec-nakn-discourse-and-digital-practices-doingdiscourse-analysis-in-the-digital-era-1-ny2015.html

Marwick, A.E. (2013). Online identity. A companion to new media dynamics, 355-364.

Mathew, W. (May 18, 2021). How Social Media Challenges Become Wildly Successful. Recovered from https://www.meltwater.com/en/blog/successf ul-social-media-challenges 
Omar, B., \& Dequan, W. (2020). Watch, share or create: The influence of personality traits and user motivation on TikTok mobile video usage. iJMI, 4(14), 121-137. Recovered from https://doi.org/10.3991/ijim.v14i04.12429

Papacharissi, Z. (2002). The Presentation of Self in Virtual Life: Characteristics of Personal Home Pages. Journalism and Mass Communication Quarterly, 79(3), 643-660.

Papacharissi, Z. (2010). A Networked Self: Identity, Community, and Culture on Social Network Sites. New York: Routledge.

Porter, J. (September 7, 2021). TikTok reportedly overtakes YouTube in US average watch time. The Verge. Recovered from https://www.theverge.com/2021/9/7/226605 16/tiktok-average-watch-time-youtube-usandroid-app-annie

Pressgrove, G., McKeever, B.W., \& Jang, S.M. (2018). What is Contagious? Exploring why content goes viral on Twitter: A case study of the ALS Ice Bucket Challenge. International Journal of Nonprofit and Voluntary Sector Marketing, 23(1), e1586. Recovered from https://doi.org/10.1002/nvsm.1586

Shafigullina, A.V., \& Palyakin, R.B. (2016). Social media marketing as an effective instrument of the promotion of social business-project in social entrepreneurial activity. Academy of Marketing Studies Journal, 20, $1 . \quad$ Recovered from https://www.researchgate.net/publication/31 1802010_Social_media_marketing_as_an_ef fective_instrument_of_the_promotion_of_so cial_business-

project_in_social_entrepreneurial_activity
Subrahmanyam, K., \& Šmahel, D. (2011). Constructing identity online: Identity exploration and self-presentation. In Digital Youth, pp. 59-80. Springer, New York, NY. ISBN 978-1-4419-6278-2. Recovered from https://www.springer.com/gp/book/9781441 962775

TikTok. (February, 2021). Terms of Service. Recovered from https://www.tiktok.com/legal/terms-ofservice?lang=en

Van Dijk, T.A. (1995). Aims of critical discourse analysis. Japanese discourse, 1(1), 17-27. Recovered from http://discourses.org/OldArticles/Aims\%20o f\%20Critical\%20Discourse\%20Analysis.pdf

Van Dijk, T.A. (2008). Discourse and power. Macmillan International Higher Education. ISBN-10: 0230574092

Van Dijk, T.A. (2009). Society and discourse: How social contexts influence text and talk. Cambridge University Press. DOI:10.1017/CBO9780511575273

Wynn, E., \& Katz, J.E. (1997). Hyperbole Over Cyberspace: Self-Presentation and Social Boundaries in Internet Home Pages and Discourse. Information Society, 13(4), 297$327 . \quad$ Recovered from https://doi.org/10.1080/019722497129043

Yang, G. (2016). Narrative Agency in Hashtag Activism: The Case of \#BlackLivesMatter. Media and Communication, 4(4), 13-17. Recovered from https://doi.org/10.17645/mac.v4i4.692 